\title{
Application of paddy planting calendar (KATAM) in Bengkayang District, West Kalimantan, Indonesia
}

\author{
Dina Omayani Dewi*, Tietyk Kartinaty, and Tuti Sugiarti
}

Assessment Institute for Agricultural Technology of West Kalimantan Jl. Budi Utomo No. 45 Siantan Hulu, North Pontianak 78241 West Kalimantan

\begin{abstract}
The rice field harvested area in West Kalimantan decreases each year around $0.96 \mathrm{kw} / \mathrm{ha}$ from 2013 . The decline in rice production is due to climate change. The objective of this study to determine the potential and constraints of developing Planting Calendar (KATAM) to anticipate the impact of climate change in West Kalimantan. The study was conduct in Tujuh Belas Sub District, Bengkayang District, West Kalimantan from January to December 2018. This study was performed using demonstration plot by comparing the existing farming system, KATAM, and introduced technology. The analysis used a randomized block design (RBD), where each treatment was repeated 3 times. The result showed that the vegetative parameters for the height of the existing treatment were higher than other treatments $(76.40 \mathrm{~cm})$. For the parameters of the number of tillers, KATAM and Introduction pattern had a large number of tillers, namely around 18 per plant. The treatment with KATAM pattern also had a high number of pithy unhulled grains and low unhulled rice (139 and 42 unit/penicle). The weight of 1000 seeds and yield per hectare, the treatment using KATAM pattern had a higher weight and yield (27.07 gr and 5.30 ton / ha).
\end{abstract}

\section{Introduction}

Climate change is a condition characterized by changes in world climate patterns that result in erratic weather phenomena. Climate change occurs due to changes in climate variables, such as air temperature and rainfall, which occur continuously over a long period of time between 50 and 100 years [1]. Climate change is also influenced by unstable weather conditions, for example erratic rainfall, frequent storms, extreme air temperatures, and drastic changes in wind direction [2].

Global climate change will affect at least three climate elements and natural components that are closely related to agriculture, namely: (a) rising air temperature which also affects other climatic elements, especially humidity and atmospheric dynamics, (b) changing rainfall patterns and increasing intensity extreme climatic events (climate anomalies) such as EI-Nino and La-Nina, and (c) rising sea levels due to melting of arctic icebergs.

\footnotetext{
* Corresponding author: malyaputri@yahoo.com
} 
Apart from reducing productivity, shifting seasons and increasing the intensity of extreme climatic events, especially drought and flooding, are also the cause of shrinkage and fluctuations in planting areas as well as expanding cropping areas that will fail harvests, especially on food crops and other seasonal crops. Therefore, climate change and extreme climate events such as EI-Nino and La-Nina will threaten national food security, and the sustainability of agriculture in general. As an illustration, one EI-Nino (weak-moderate) event can reduce national rice production by $2-3 \%$. If the extreme climate is followed by an increase in air temperature, the decline in rice production will be higher.

The increase in temperature causes an increase in transpiration which in turn reduces the productivity of food crops [3], increases water consumption, accelerates the ripening of fruit /seeds, reduces the quality of yields, and encourages the development of plant pests. Based on the results of plant simulations, an increase in temperature of up to $2{ }^{\circ} \mathrm{C}$ in lowland areas can reduce production by up to $40 \%$, while in the medium and high plains the decline in production is around $20 \%$ [4]. The results of research [5] show that every increase in temperature of at least $1{ }^{\circ} \mathrm{C}$ will reduce rice yields by $10 \%$. [6] showed that an increase in temperature of $1{ }^{\circ} \mathrm{C}$ will reduce production by $5-7 \%$. This decrease is due to reduced sink formation, shorter growth periods, and increased respiration [7].

Global warming caused by increasing concentrations of greenhouse gases (GHG) has also led to climate change. In the agricultural sector, especially in the food crop sub-sector, the impacts of climate change have been increasingly felt, such as the threat of floods, drought, attacks by plant pests (OPT), decreased quality and quantity of production. The rice field harvested area in West Kalimantan in 2013 was 360,923 ha and in 2014 it was 356,843 ha, where there was a decrease of 4,080 ha. With the average production decreasing by around $0.96 \mathrm{kw} /$ ha from 2013. Therefore, it is necessary to anticipate the impacts of climate change.

In the government's efforts to minimize the negative impacts of climate change, with the preparation of the Integrated Planting Calendar Information System (Katam) by The Agency of Agricultural Research and Development Ministry of Agriculture. This system is expected to be used as a guide or information for farmers and agricultural policy makers to predict the season, early planting, cropping patterns, potential planting area, vulnerable areas floods and droughts, potential pest attacks, rice varieties and seed requirements, and recommended dosage and fertilizer requirements based on prediction of variability and change climate up to sub-district level

Efforts to increase production require a careful strategy based on accurate climate forecasts, including through accelerated planting in several locations, especially in areas with high rainfall. Adjustment of planting times and cropping patterns is a strategic approach in adapting the impacts of climate change due to shifting planting seasons and changing rainfall patterns. Planting time and cropping patterns are arranged based on several climate change scenarios, in particular the pattern and amount of rainfall. Planting pattern development activities are carried out by applying the Integrated SI KATAM recommendation through optimization of land use. The development of cropping patterns is aimed at increasing land productivity by increasing the number of plants per year or by diversifying farm products. The final impact expected from the development of cropping patterns is an increase in farm productivity and farmer income. This study aims to determine the potential and constraints of developing Planting Calendar (KATAM) in anticipation of climate change in West Kalimantan. 


\section{Methodology}

\subsection{Time and location}

The research was conducted from Januari to Desember 2018 in Tujuh belas Sub District, Bengkayang District, West Kalimantan.

\subsection{Respondents}

Farmers of the research were owner-farmers of the rice-field. Samples were determined using incidental sampling method, in which the samples were directed to everyone who were met by the researcher, and of course, they had rice-field conversion, and it has been done due to no data existed about population of the farmers who converse their rice-fields. There are 10 farmers involved in this activity from Tujuh Belas subdistrict, Kab. Bengkayang, West Kalimantan.

\subsection{Data collection and analysis}

The data collection methods used in this study were observation, and interviews. The experimental design used randomized block design (RBD), where each treatment was repeated 3 times. Data collected were statistically analyzed using two-ways analysis of variance (ANOVA), and Duncan's new multiple range test (DMRT) was employed to determine the mean differences between the treatments using the statistical analysis. The treatment in this study is shown in the following table:

Table 1. Recommendations on Rice Cultivation Technology based on Treatment

\begin{tabular}{|c|c|c|c|c|}
\hline \multirow[b]{2}{*}{ No } & \multirow[b]{2}{*}{ Treat ment } & \multicolumn{3}{|c|}{ Recommendation } \\
\hline & & Existing & КАТАМ & $\begin{array}{l}\text { Introduced } \\
\text { Technology }\end{array}$ \\
\hline 1 & Planted Area (ha) & 0.25 & 0.25 & 0.25 \\
\hline 2 & Time of Planting & May I-April II & Aug III-Sep I & Aug III-Sep I \\
\hline 3 & Spacing $(\mathrm{cm})$ & $25 \times 25$ & $25 \times 25$ & $25 \times 25$ \\
\hline 4 & Planting system & Jarwo & Jarwo & Jarwo \\
\hline 5 & Varieties (Rice) & Mekongga & Inpari 42 & Inpari 24 \\
\hline \multirow[t]{5}{*}{6} & Fertilizer & & & \\
\hline & - Urea (kg / ha) & 0 & 100 & 100 \\
\hline & - NPK 15-15-15 (kg/ha) & 300 & 250 & 300 \\
\hline & - SP (kg / ha) & 300 & 0 & 300 \\
\hline & - Chicken manure (t/ha) & 0 & 2 & 2 \\
\hline
\end{tabular}

\section{Results and discussion}

\subsection{Geographical conditions of Bengkayang District}

Bengkayang District is one of the district located in the North of West Kalimantan Province. Geographically, Bengkayang District is located at $0^{0} 33^{\prime} 00^{\prime \prime}$ to $1^{0} 30^{\prime} 00^{\prime \prime}$ North Latitude and $1^{0} 8^{0} 39^{\prime} 00^{\prime \prime}$ to $110^{\circ} 10^{\prime} 00^{\prime \prime}$ East Longitude. Administratively, the boundaries of the Bengkayang District are as follows:

North : Sarawak-East Malaysia and Sambas District

South : Pontianak District

West : Natuna Sea and Singkawang City 


\section{East : Sanggau District and Landak District}

Bengkayang Regency generally has a tropical climate with an average monthly air temperature ranging from $22.9 \mathrm{C}$ to $31.05 \mathrm{C}$, an average monthly relative humidity of $86 \%$, and the intensity of sunlight being $38 \%$. Fairly high rainfall in September to January and low rainfall between June to August.

\subsection{Characteristics of cropping pattern}

The development of a cropping pattern in Pisak village, seventeen sub-districts can be described as follows:

\begin{tabular}{|l|l|l|l|l|l|l|l|l|l|l|l|}
\hline Jan & Feb & Mar & Apr & May & June & July & Aug & Sept & Oct & Nov & Des \\
\hline \multicolumn{8}{|c|}{ Pepper } \\
\hline \multicolumn{8}{|c|}{ Palm oil } \\
\hline \multicolumn{8}{|c|}{ Vegetable horticultural crops } \\
\hline
\end{tabular}

Fig 1. Characteristics of Cropping patterns in Pisak village, Tujuh Belas Sub District, Bengkayang District, West Kalimantan

Based on the picture above, it can be seen that the characteristics of the cropping pattern in Pisak Village, Tujuh Belas Sub District, Bengkayang District, the commodities of pepper and oil palm plantations are the dominant commodities cultivated by farmers throughout the year. For pepper plants that develop are local varieties of pepper, the peak planting occurs in the rainy season, from September to December because at the beginning of the growth of pepper seeds, they really need water, while the planting of oil palm commodities occurs throughout the season.

For horticultural commodities that are growing are vegetable crops such as chilies, tomatoes, beans, luffa, long beans, eggplant and cucumber. This vegetable commodity is cultivated throughout the year because it has quite good commercial and marketing value, namely in Malaysia.

For food crops commodities that are predominantly cultivated are rice and maize, for local rice plants are generally cultivated in the low season, namely the varieties developed are Belitang rice with a plant age of \pm 5 months. Belitang Rice is very popular because it has a fragrant and fluffier aroma, generally this rice is not sold and only for self-consumption. In addition, superior rice has been developed, namely the ciherang and mekongga varieties, which are cultivated only for consumption. Dominan pests that attack rice fields are orongorong, stem borer, rodents and stink bugs. Production in Pisak Village, Tujuh Belas Sub District, Bengkayang District is generally still low, namely local rice $1.5-2$ tons / ha and superior rice ranging from 3-4 tons / ha.

\subsection{Growth component and yield}

From the observation, there is no significant effect of technology toward plant height, number of tiller, empty grain/penicle, and weight of 1000 grain. 
Table 2. Observation Data of Rice Plants in Vegetative and Generative Phases in Pisak Village, Tujuh Belas Sub District, Bengkayang District Year, 2018

\begin{tabular}{lcccccc}
\hline Treatment & $\begin{array}{c}\text { Height } \\
(\mathbf{c m})\end{array}$ & $\begin{array}{c}\text { Number } \\
\text { of } \\
\text { Tillers }\end{array}$ & $\begin{array}{c}\text { Pithy } \\
\text { Grains/ } \\
\text { penicle } \\
\text { (unit) }\end{array}$ & $\begin{array}{c}\text { Empty } \\
\text { Grain/ } \\
\text { penicle } \\
\text { (unit) }\end{array}$ & $\begin{array}{c}\text { Weight } \\
\mathbf{1 0 0 0} \\
\text { Grains } \\
(\mathbf{g})\end{array}$ & $\begin{array}{c}\text { Yield } \\
\left(\mathbf{t ~ h ~}^{-1} \text { ) }\right.\end{array}$ \\
\hline Existing & $76.40^{\mathrm{a}}$ & $17.87^{\mathrm{a}}$ & $92.13^{\mathrm{a}}$ & $71.00^{\mathrm{a}}$ & $23.58^{\mathrm{a}}$ & $3.07^{\mathrm{a}}$ \\
KATAM & $75.33^{\mathrm{a}}$ & $18.53^{\mathrm{a}}$ & $139.87^{\mathrm{b}}$ & $42.33^{\mathrm{a}}$ & $27.07^{\mathrm{a}}$ & $5.30^{\mathrm{c}}$ \\
$\begin{array}{l}\text { Introduced } \\
\text { Technology }\end{array}$ & $76.33^{\mathrm{a}}$ & $18.46^{\mathrm{a}}$ & $124.80^{\mathrm{ab}}$ & $73.33^{\mathrm{a}}$ & $23.64^{\mathrm{a}}$ & $4.73^{\mathrm{b}}$ \\
\hline
\end{tabular}

The higher plant height resulted in more plant populations in one stretch. High plant growth does not guarantee high plant productivity. Plants that grow well are able to absorb nutrients in large quantities, the availability of nutrients in the soil affects plant activities including photosynthetic activity, so that plants can increase growth and production [8]. Furthermore, the height of the plant stem is influenced by the nature or characteristics that affect the yield of varieties. Based on the characteristics of plant height, varieties that have short plant heights can be caused by several factors such as climatic factors or other factors. The taller the plant, the higher the tendency to fall. Varieties with short stems will absorb more sunlight than tall varieties. With long stems, the intensity of sunlight that penetrates the canopy (canopy) of the plant to the bottom of the plant above ground level will be much reduced [9]

The number of grain contents per panicle will determine the productivity of the plant if the panicles formed produce a lot of pithy rice, then the productivity of rice plants is high [10]. The amount of grain content is determined by the number of productive tillers and early flowering age, where pollination will be successful and produce a lot of pithy rice. The filling process of rice paddy through starch in plants originating from photosynthetic sources and assimilation sources before flowering which is stored in stem and leaf tissue is then converted into sugar and transported to grain [11].

The weight of 1000 seeds for each treatment was not significantly different. This is presumably because the shape and size of the seeds are determined by genetic factors so that the weight of 1000 grains produced is almost the same. The high and low weight of the seeds depends on the amount of dry matter contained in the seeds [12]. The dry matter in the seeds is obtained from photosynthesis which can then be used for filling seeds. The recommendation technology with KATAM significantly affected pithy grains/panicle which was around 139 unit per panicle. The plants with high yield potential have a low percentage of empty grain. The lower the percentage of empty grain, the higher the percentage of filled grain [13].

There are several factors that affect the height of empty grain in rice plants, one of which is the attack of Stink bug. The Stink Bug (Leptocorisa acuta T.) is a pest that is almost certainly always present in every rice season. This pest destroys rice grains during the ripening phase, by sucking the grains of grain that are filling. This causes damage in the form of discolored rice and calcifies and the grain becomes empty. The attack of one stink bug per panicle in one week can reduce the yield by $27 \%$ [14]. The decline in the stink bug population occurred at the last observation at the age of 21 week after planting in all observation locations. This happens because the rice seeds that are used as food ingredients have started to harden. If the plants that are used as food are not suitable, it will adversely affect the life of these insects [15].

The global climate change can also result in the dynamics of plant-disturbing organisms, namely an increase in pest and disease attacks in rice fields in Indonesia [16]. The cause of the pest attack is due to the influence of climate [17]. Hot temperature conditions accompanied by rain will affect the increase in the development of the pest population of 
walang sangit. The development of the walang sangit population in favorable climatic conditions is very fast, especially when accompanied by the availability of food, it will cause the population to experience a very sharp increase so that it can cause a wider attack.

As well as the weight parameter of 1000 seeds of treatment The KATAM pattern has a weight of 1000 seeds that is greater than the other treatments so that the production is also higher, which is around 5.30 tonnes / ha. Setting of the right planting time and optimal use of fertilizers greatly affect the results obtained.

\section{Conclusion}

The recommendation technology with KATAM significantly affected pithy grains/panicle which was around 139 unit per panicle. For the weight of 1000 seeds and yield per hectare, the treatment using KATAM had a higher weight and yield, namely $27.07 \mathrm{~g}$ and $5.30 \mathrm{t} / \mathrm{ha}$.

\section{References}

1. Ministry of Environment. 2004. Global climate change http://climatechange.menlh.go.id.

2. Ratnaningayu. 2009. From Timor to Krui: how farmers and fishermen face the impacts of climate change, climate workshop, Jakarta, November 2009. Pelangi Indonesia.

3. I. Las, 2007. Strategies and Innovations to Anticipate Climate Change, Sinar Tani Edition 14 - 20 November 2007.

4. E. Surmaini, E. Runtunuwu, I. Las, J. Agric. Research and Development, 30, (2011)

5. Peng, S., J. Huangm J.F. Sheehy, R.C. Laza, R.M. Visperas, X. Zhong, G.S. Chenteno, G.S. Kush, and K.G. Chassman. Proc. Natl. Acad. Sci. USA. 101, (2004)

6. R. B. Matthews, M.J. Kropff, T. Horie, D. Bachelet. Agric. Syst. 54, (1997)

7. R. B. Matthews, R. Wassmann, J. Agronomy 19, (2003)

8. Aribawa, 2012. The effect of the cropping system on increasing rice productivity in upland wet climates. Center for the Assessment of Agricultural Technology (BPTP) Bali. Denpasar.Http//pertanian.trunojoyo.ac.id

9. B. Suprihatno, Description of Rice Varieties. Center for Rice Research, Agency for Agricultural Research and Development, Ministry of Agriculture Sukamandi 2010.

10. W. A. Suryanugraha, Supriyanta, Kristamtini. Vegetalika 6, 4, (2017)

11. P. Wibowo, 2010. Growth and Productivity of Hybrid Hope Line (Oryza Sativa L.) In Ketaon Village, Banyudono District, Boyolali. Department of Agronomy, Faculty of Agriculture, Sebelas Maret University

12. Masdar. J. Akta Agrosia, 1, (2017)

13. Suparwoto, Waluyo, Jumakir. J. Agronomy 8, (2004)

14. Indonesian Center for Rice Research. Walang Sangit Pests. BB Rice; Sukamandi, Subang, West Java. (2009)

15. Rismunandar, Food Plant Pests and Their Eradication. Sinar Baru Alegesindo. Bandung, 1993

16. S. E.Baehaki, B. Abdullah, 2008, Evaluation of the resistance character of rice lines against brown planthopper biotype 3 through screening and population built up tests. Proceedings of the seminar on the appreciation of rice research results support P2BN. Book I. Center for Rice Research, Agency for Agricultural Research and Development. (2008)

17. Fattah, A. Hamka. 2011. Rates of Major Pests of Rice in Two Different Seasons in South Sulawesi. Seminar and Annual Meeting of the XXI PEI, PFI South Sulawesi Komda and the Plantation Office of the South Sulawesi Provincial Government on 7 June 2011 at Singgasana Hotel Makassar. 